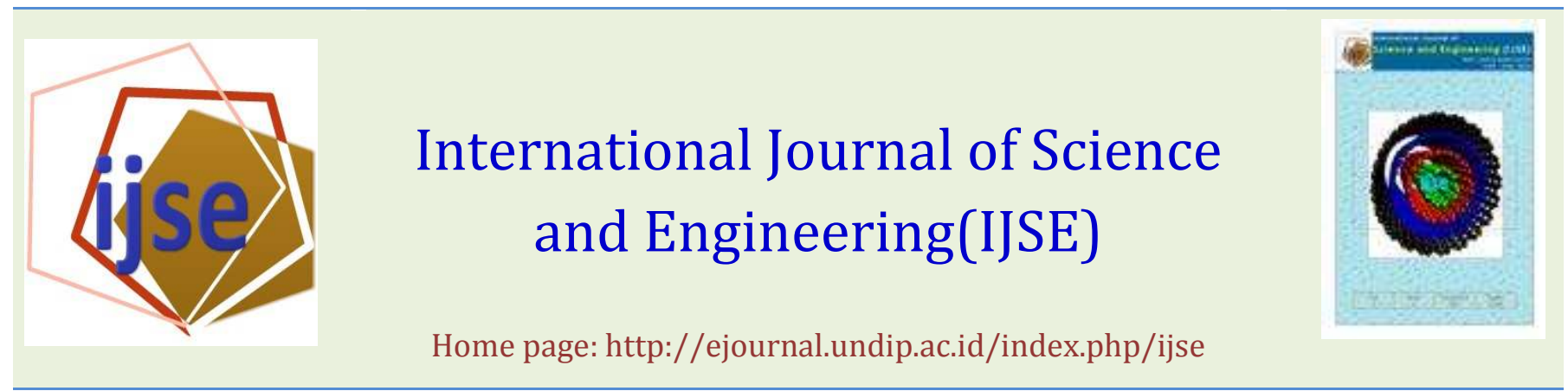

\title{
Immobilized bacteria by using PVA (Polyvinyl alcohol) crosslinked with Sodium sulfate
}

\author{
Pham Van Dinh ${ }^{1}$, LeuTho Bach ${ }^{2}$ \\ National University of Civil Engineering, Vietnam \\ No. 55, GiaiPhong Road, Hanoi, Vietnam \\ 1dinhxd.iese@gmail.com;2leuthobach@gmail.com
}

\begin{abstract}
A new bacteria immobilization technique using PVA (polyvinyl alcohol) crosslink with sodium sulfate was developed. This new technique can simultaneously eliminate the agglomeration of PVA beads and the toxicity of boric acid caused by the PVA-boric methods, also reducing the swelling (when soaking in water) of PVA-boric methods. Beads were immobilized by using four different PVA entrapment processes to create group B, group N, group P and group S. The stability, swelling, relative mechanical strength of the PVA beads were compared in this study. Only group S was the best and chosen to do experiment for checking survival of bacteria after immobilization process and TOC removal performance of anaerobic reactor. The TOC removal performance of anaerobic reactor achieved $80-87 \%$.
\end{abstract}

Key words: PVA-alginate beads; immobilized bacteria; bacterial gel bead.

Submission: June 4, $2014 \quad$ Correction: July 4, 2014

Accepted: July 8, 2014

Doi: $10.12777 /$ ijse.7.1.41-47

[How to cite this article: Dinh, P.V. and Bach, L.T. 2014. Immobilized bacteria by using PVA (Polyvinyl alcohol) crosslinked with Sodium sulfate, 7(1),41-47. Doi:10.12777/ijse.7.1.41-47]

\section{Introduction}

The enzymes and bacteria are the core of the biological treatment process from the activated sludge, anaerobic treatment, to the anammox. All these processes are considered to be economical effective treatment if possible to reduce the hydraulic retention time in these process; increase the processing load of organic matter, it means that the treatment reactor will be smaller and reduce energy consumption for mixing and pumping. All most of the current biological process then bacteria exist in suspended sludge form, there are some following disadvantages: 1- Difficult to control the concentration of sludge in treatment reactors; 2- Waste-out of sludge from reactors. 3- The suspended sludge is very difficult settling in mechanical treatment process. Thus, required the design of the treatment system with long hydraulic retention time (HRT) and/or reactor with big volume. So, if we want to decrease the HRT and easily to control the sludge (Bacteria) concentration, we need to have solutions to immobilize bacteria.

Immobilization of living cells has become a technique for increasing the productivity of biochemical engineering processes. One of the most widely used techniques for bacterial immobilization is bacterial entrapment, in which, the bacteria (living cells) are enclosed in a polymeric matrix which has porous enough to allow the diffusion of substrates to the bacteria and of products away from the bacteria. Materials which have been successfully used for cell entrapment include agar, agarose, kappa-carrageenan, collagen, alginate, chitosan, polyacrylamide, polyurethane, and cellulose [1]. However, each of these polymers has drawbacks, such as poor mechanical strength and durability (agar, agarose, kappacarrageenan, collagen, alginates, chitosan), toxicity to microorganisms (polyacrylamide, polyurethane), or high cost $[2,3]$.

The use of poly vinyl alcohol (PVA) as an immobilization matrix was initiated about more than 30 years ago by Freeman and Aharonowitz [4]. A few years later, PVA gels have been successfully used in bioremediation particularly in wastewater treatment [2, 5]. Besides that, PVA is the largest synthetic water soluble polymer produced in the world [6]; and PVA offers various advantages over the conventional alginate hydrogels including lower cost, higher durability and chemical stability, and its non-toxicity to viable cells [7]. PVA gel exhibits a high degree of swelling in water (or biological fluids) and it is also rubbery and elastic in nature [8]. The highly hydrophilic PVA must be crosslinked either chemically or physically to make it insoluble [9]. Ariga et al [2] used the technique of iterative freezing and thawing of PVA to form a gel suitable for cell immobilization. They found that this technique produced a low-cost material with a rubber-like elasticity and high strength. Hashimoto and Furukawa [5] used a simpler and less energy-intensive method for PVA immobilization. 
Crosslink the PVA used a boric acid solution. The PVAboric acid technique provides an easy method of immobilization cell, producing elastic beads of high strength and durability [5]. There are two potential problems with this technique, however. The saturated boric acid solution used to crosslink the PVA is highly acidic ( $\mathrm{pH}$ of approximately 4), thus could cause difficulty in maintaining cell viability. In addition, PVA is an extremely sticky material. PVA beads, therefore have a tendency to agglomerate [10]. This is particularly a problem in applying PVA-immobilized cells to fluidized bed reactors.

In this study, the agglomeration and swelling problem of the PVA-boric acid method are eliminated by the addition of a small amount of calcium alginate. After that, other different kinds of bead are performed by soaking PVA-boric in solutions of $\mathrm{Na}_{2} \mathrm{SO}_{4}-0.5 \mathrm{M}$; $\mathrm{NaNO}_{3}-0.5 \mathrm{M}$ and $\mathrm{NaH}_{2} \mathrm{PO}_{4}-0.5 \mathrm{M}$, respectively. The main focus of this study is to investigate the feasibility of these methods; to find the reasonable ratio between PVA, sodium alginate and sludge used in forming beads; to compare relative strength between kinds of produced beads; to check survival of bacteria after immobilization process; to test effective of anaerobic reactor when presence of beads.

\section{Materials and methods}

\subsection{Activated sludge}

Sludge was collected from the Kim Lien Wastewater Treatment Plant in Hanoi, Vietnam.

\subsection{Chemicals}

Polyvinyl Alcohol - PVA $\left(\mathrm{C}_{2} \mathrm{H}_{4} \mathrm{O}\right)_{\mathrm{n}}$ was bought from Kuraray Co.,ltd (Singapore). Grade is $98 \%-100 \%$ hydrolyzed and molecular weight 77000 [11].

Sodium Alginate $\left(\mathrm{C}_{6} \mathrm{H}_{7} \mathrm{O}_{6} \mathrm{Na}\right) \mathrm{n}$; Calcium Chloride $\left(\mathrm{CaCl}_{2}\right)$; Boric acid $\left(\mathrm{H}_{3} \mathrm{BO}_{3}\right)$; Sodium Sulfate $\left(\mathrm{Na}_{2} \mathrm{SO}_{4}\right)$; Sodium Nitrate $\left(\mathrm{NaNO}_{3}\right)$; MonoSodium Phosphate $\left(\mathrm{NaH}_{2} \mathrm{PO}_{4}\right) ; \mathrm{C}_{6} \mathrm{H}_{12} \mathrm{O}_{6}$; Wilson Blair agar were purchased in Hanoi, Vietnam.

\subsection{Methods of immobilization}

Prepare these following solutions: $500 \mathrm{ml}$ of $0.5 \mathrm{M}$ $\mathrm{NaH}_{2} \mathrm{PO}_{4}$ Solution; $500 \mathrm{ml}$ of $0.5 \mathrm{M} \mathrm{Na}_{2} \mathrm{SO}_{4}$ solution; $500 \mathrm{ml}$ solution with saturated $\mathrm{H}_{3} \mathrm{BO}_{3}(5-7 \% \mathrm{w} / \mathrm{v})$ and added $\mathrm{CaCl}_{2}(2 \% \mathrm{w} / \mathrm{v}) ; 500 \mathrm{ml}$ of $\mathrm{NaNO}_{3}$ solution $(50 \% \mathrm{w} / \mathrm{v})$; $50 \mathrm{ml}$ of Sodium alginate solution $(5 \% \mathrm{w} / \mathrm{v})$.

Add water to a beaker (was available $10 \mathrm{~g}$ of PVA) to obtain $70 \mathrm{ml}$ solution. This solution was then heat to a temperature of around $80^{\circ} \mathrm{C}$ to dissolve PVA. $20 \mathrm{ml}$ Sodium alginate solution $(5 \% \mathrm{w} / \mathrm{v})$ was added to the PVA solution. The PVA-alginate solution was then cooled to around room temperature. Next, $10 \mathrm{ml}$ of activated sludge was added in the PVA-alginate solution. In fact, this solution has PVA $(10 \%, \mathrm{w} / \mathrm{v})$, Sodium alginate $(1 \%, \mathrm{w} / \mathrm{v})$, activated sludge $(10 \%, \mathrm{v} / \mathrm{v})$ [11]. We changed concentration of PVA and sodium alginate to have some different solutions for comparing. This solution was named A solution.

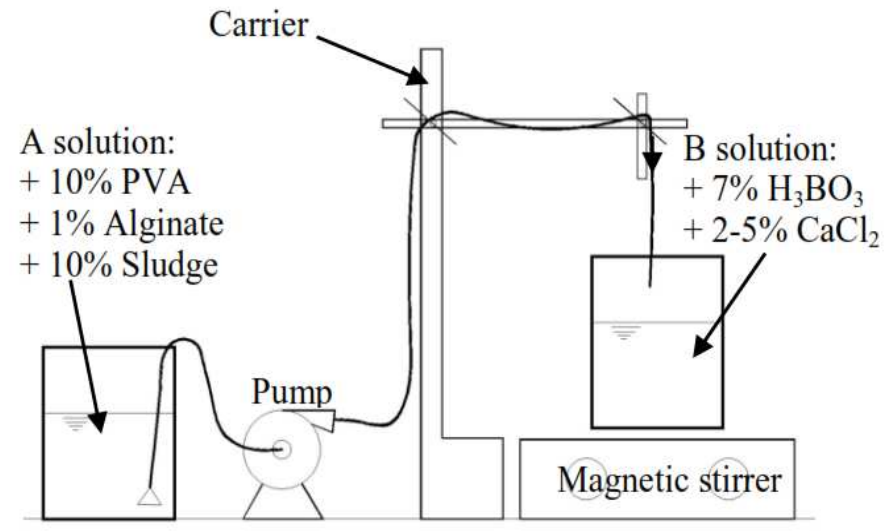

Fig. 1: Diagram of creation PVA beads

The A solution was dropped into $\mathrm{B}$ solution: saturated $\mathrm{H}_{3} \mathrm{BO}_{3}(7 \%, \mathrm{w} / \mathrm{v})$ and $\mathrm{CaCl}_{2}(2 \%, \mathrm{w} / \mathrm{v})$. And immersed for 1 hour to form PVA-Boric beads (group B) (Fig. 1). The beads were then removed, washed and stored at $4{ }^{\circ} \mathrm{C}$ in the pure water. PVA-phosphate beads (group P) were prepared by transferring the beads (group B) to $0.5 \mathrm{M} \mathrm{NaH}_{2} \mathrm{PO}_{4}$ solution and immersing for 1 hour. PVA-sulfate beads (group S) were prepared by transferring the beads (group B) to $0.5 \mathrm{M} \mathrm{Na}_{2} \mathrm{SO}_{4}$ solution and immersing for 1 hour. PVA-nitrate beads (group N) were prepared by transferring the beads (group B) to $50 \% \mathrm{NaNO}_{3}$ solution and immersing for 1 hour. (All beads were then removed, washed and stored at $4^{\circ} \mathrm{C}$ in the pure water until using).

\subsection{Test of relative mechanical strength}

The Rotana 460 centrifuge (HitechCo.,ltd) with 4plates in Swing-out rotor was used to determine the relative mechanical strength of the PVA beads. Radius of rotary was $203 \mathrm{~mm}$. The beaker was $62 \mathrm{~mm}$ in diameter, $137 \mathrm{~mm}$ in height. Twenty beads of various kinds were added to the beaker and the water level adjusted with pure water to $10 \mathrm{~cm}$ in height. The centrifuge was controlled from 500-3000 rpm. The beads were agitated in the beaker for $5 \mathrm{~min}$ and the surviving beads counted.

\subsection{Test swelling of beads in the water}

The beads will use for wastewater treatment. Thus, experiment to determining mechanical strength of beads in the water is necessary. 20 beads of various kinds were dropped into the water bottle (size $500 \mathrm{ml}$ ), and the beads were stirred by magnetic stirrer machine. Daily, These bottles water were changed pure water inside them and observation was memorized.

\subsection{Check survival of bacteria after immobilization}

The sludge (which was composition of the beads) had many spores of sulfite-reducing bacteria. If these spores can still survival after immobilization process, it means this immobilization method is suitable. To check survival of bacteria, this study used Wilson Blair agar as an indicator.

Some beads of the best kind in bead types were washed by $0.9 \% \mathrm{NaCl}$ solution. Wilson Blair agar in a glass tube was taken from refrigerator, and heated at $90^{\circ} \mathrm{C}$ about $30 \mathrm{~min}$ to be hydrolyzed completely. After 
that, glass tube was decreased temperature to $45^{\circ} \mathrm{C}$. Finally, some beads were inserted inside Wilson Blair agar. This glass tube was kept at $37^{\circ} \mathrm{C}$ and observed following $24 \mathrm{~h}, 48 \mathrm{~h}$.

\subsection{Test of performance in anaerobic reactor}

The best kind of bead types was released into a reactor to check effective treatment of reactor when appearing the beads. Fig. 2 shows schematic diagram of the reactor system. The reactor had a volume of $500 \mathrm{ml}$; Volume of beads was $50 \mathrm{ml}$.

Temperature of the reactor was kept by water tank at $37^{\circ} \mathrm{C}[12]$. Substrate and nutrients water in this study follow as Bach, Bhatti [13]. The synthetic wastewater consisting components as shown in Table 1; and Table 2 was used as trace substrate. Sucrose $\left(\mathrm{C}_{6} \mathrm{H}_{12} \mathrm{O}_{6}\right)$ was used as the sole carbon source in feeding, concentration of TOC in water was kept at $5 \mathrm{~g} / \mathrm{l}$. $\mathrm{N}$ and $\mathrm{P}$ were added in the form of $\mathrm{NH}_{4} \mathrm{Cl}$ and $\mathrm{KH}_{2} \mathrm{PO}_{4}$ in accordance with COD: $\mathrm{N}: \mathrm{P}$ ratio = 300:5:1[14].

At fixed time in everyday, aspirate $51 \mathrm{ml}$ of water from the reactor. After that, inject $50 \mathrm{ml}$ of nutrient water and $1 \mathrm{ml}$ of saturated sodium bicarbonate as a buffer.

TOC and $\mathrm{pH}$ of effluent water were measured follow as standards in Table 3.

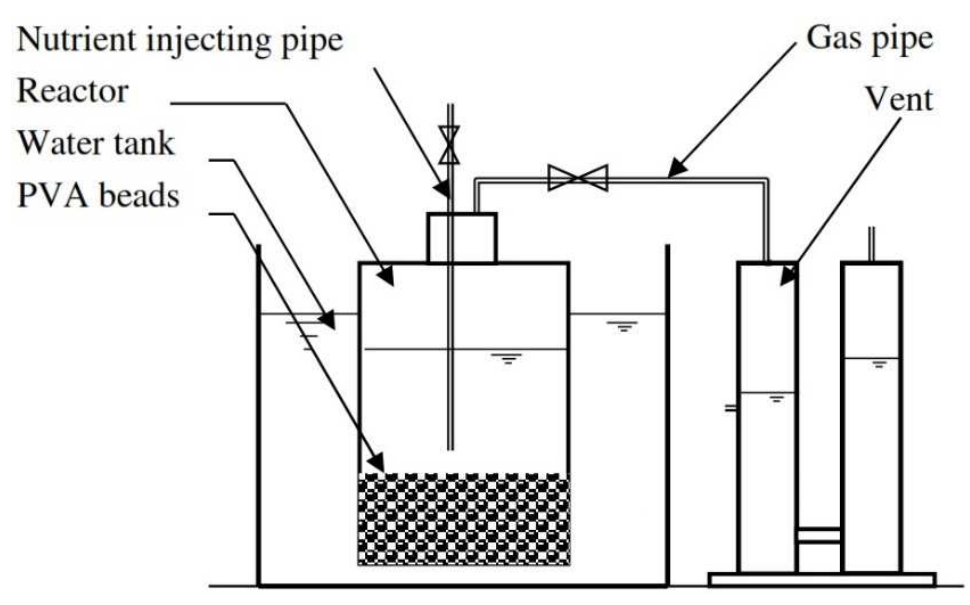

Fig. 2: Schematic view of the reactor system

Table 1: Compositions of synthetic wastewater

\begin{tabular}{c|c}
\hline Components & Concentration \\
\hline $\mathrm{C}_{6} \mathrm{H}_{12} \mathrm{O}_{6}$ & $12.5 \mathrm{~g} / \mathrm{l}(5 \mathrm{~g}-\mathrm{C} / \mathrm{l})$ \\
$\mathrm{NH}_{4} \mathrm{Cl}$ & According to the ratio of $\mathrm{C}: \mathrm{N}: \mathrm{P}$ \\
$\mathrm{KH}_{2} \mathrm{PO}_{4}$ & According to the ratio of C:N:P \\
$\mathrm{MgSO}_{4} .7 \mathrm{H}_{2} \mathrm{O}$ & $0.1 \mathrm{~g} / \mathrm{l}$ \\
Trace nutrient & $10 \mathrm{ml} / \mathrm{l}$ \\
solution & \\
\hline
\end{tabular}

Table 2: Concentration of trace nutrient solution

\begin{tabular}{cc}
\hline Trace nutrient & Concentration (mg/l) \\
\hline $\mathrm{FeCl}_{2} .6 \mathrm{H}_{2} \mathrm{O}$ & 4.9 \\
$\mathrm{MnCl}_{2} .4 \mathrm{H}_{2} \mathrm{O}$ & 0.35 \\
$\mathrm{CoCl}_{2} .6 \mathrm{H}_{2} \mathrm{O}$ & 0.085 \\
$\mathrm{ZnCl}_{2}$ & 0.35 \\
$\mathrm{NiCl}_{2} .6 \mathrm{H}_{2} \mathrm{O}$ & 0.42 \\
$\mathrm{CaCl}_{2} .2 \mathrm{H}_{2} \mathrm{O}$ & 0.35 \\
$\mathrm{H}_{3} \mathrm{BO}_{3}$ & 0.035 \\
$\mathrm{Na}_{2} \mathrm{MoO}_{3} .2 \mathrm{H}_{2} \mathrm{O}$ & 0.085 \\
$\mathrm{CuCl}_{2} 2 \mathrm{H}_{2} \mathrm{O}$ & 0.009 \\
\hline
\end{tabular}

Table 3: Analytical parameters and analytical methods

\begin{tabular}{cccc}
\hline Parameters & Analytical frequency & Analytical methods & Instruments \\
\hline $\mathrm{pH}$ & One time/ day & ISO 10523:2008 & $\begin{array}{c}\text { pH 720 inolab } \\
\text { (WTW- Germany) } \\
\text { TOC-Vcph } \\
\text { TOC }\end{array}$ \\
One time/ day & ISO 8245: 1999 & (Shimadzu-Japan) \\
\hline
\end{tabular}

\section{Results and discussion}

\subsection{Study of immobilization method}

Two potential problems in PVA-boric method are the agglomeration of PVA gel beads and the toxicity of saturated boric acid [15]. Wu and Wisecarver [10] added a small amount of calcium alginate to prevent the agglomeration of PVA gel beads. Chen and Lin [16] reduced the immersion time of saturated boric acid from 15-24 hours to $10 \mathrm{~min}-2$ hours to diminish cell damage and used an orthophosphate solution for gel strength reinforcement. The first was formation of calcium alginate membrane in Fig. 3. After that, these borate ions will crosslink the alcohol groups on adjacent chains as depicted in Fig. 4.Structure of beads bases on both links PVA-boric and Calcium-Alginate.

However, due to the aforementioned unusual semi solid properties, the beads produced could easily dissolve in distilled water. To overcome this problem, ion sulfate, ion nitrate and ion phosphate were respectively introduced, as these ions possess the ability to form linkages among the cross-linked PVA. Bead of PVA-nitrate was presented by Chang et al. [15]; Bead of PVAPhosphate was presented by Chen et al. [16]. Pillay et al. 
[17] have also introduced sodium sulfate as their crosslinking agent together with boric acid to crosslink the PVA. The overall reaction that took place during PVA- alginate bead formation is shown in Fig. 5. Similar that, Beads of group $\mathrm{N}$ and group $\mathrm{P}$ were created.

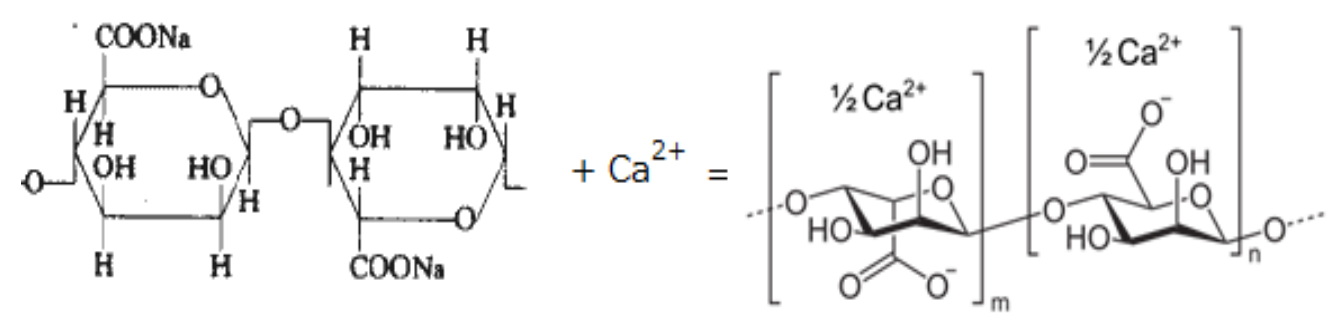

Fig. 3: Formation of Calcium alginate membrane[18]<smiles>CCC(O)CC(O)CI</smiles>

Fig. 4: Formation of PVA-Boric[19]<smiles>CCC1CC(C)O[B-]2(OC(C)CC(CC)O2)O1</smiles><smiles></smiles>

Fig. 5: Formation of PVA- sulfate [11]

\subsection{Effect of PVA and Alginate ratios on formation of group B beads}

The beads of group B were prepared according to the method explained in Section 2.3. PVA contributed strength and durability to the bead, whereas calcium alginate improved their surface properties, reducing the tendency to agglomerate. The percentage of PVA in the beads was kept in the range of $10-12 \%(w / v)$ as recommended for maximum bead strength. Various percentage of PVA was attempted for the immobilization procedure (Table 4). The percentage of alginate in the beads was also varied for immobilization to find the best percent (Table 5).
Table 4 - Influence of the percent of PVA to formation of group B

\begin{tabular}{cccc}
\multicolumn{4}{c}{ beads } \\
\hline PVA & Agglomeration & $\begin{array}{c}\text { Formation } \\
\text { of beads }\end{array}$ & Strength \\
\hline 6 & prevented & Not good & No formation \\
8 & prevented & Oval shape & weak \\
10 & prevented & good & Strong \\
12 & prevented & good & Strong \\
14 & prevented & have tail & Strong \\
\hline
\end{tabular}

Table 5 - Influence of the percentage of alginate to formation of group B beads. (Percentage of PVA was kept at 10\%)

\begin{tabular}{ccc}
\hline Agglomeration & $\begin{array}{l}\text { Formation } \\
\text { of beads }\end{array}$ & Strength \\
\hline Not prevented & $\begin{array}{c}\text { Not } \\
\text { formation } \\
\text { Oval shape }\end{array}$ & No formation \\
prevented & weak \\
prevented & Oval shape & good \\
prevented & good & good \\
prevented & good & good \\
\hline
\end{tabular}


<smiles>CC(O)CC(C)O</smiles>

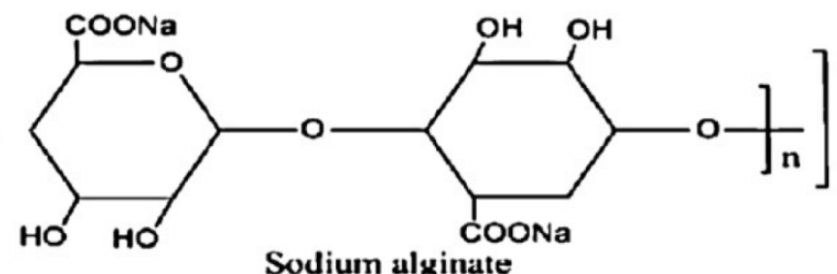<smiles>CCC1CC(C)O[B-]2(OC(C)CC(CC)O2)O1</smiles>

$+$

Sodium alginate

$\left.\mathrm{CaCl}_{2}\right]$

$\mathrm{H}_{2} \mathrm{O}$

Calcium chloride

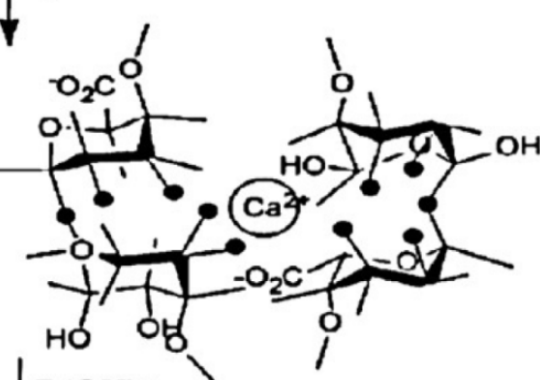

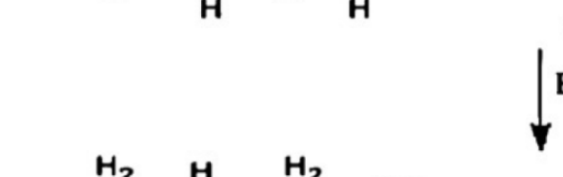<smiles>CCC1BOC(C)CC1</smiles>

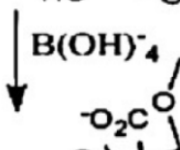
HO
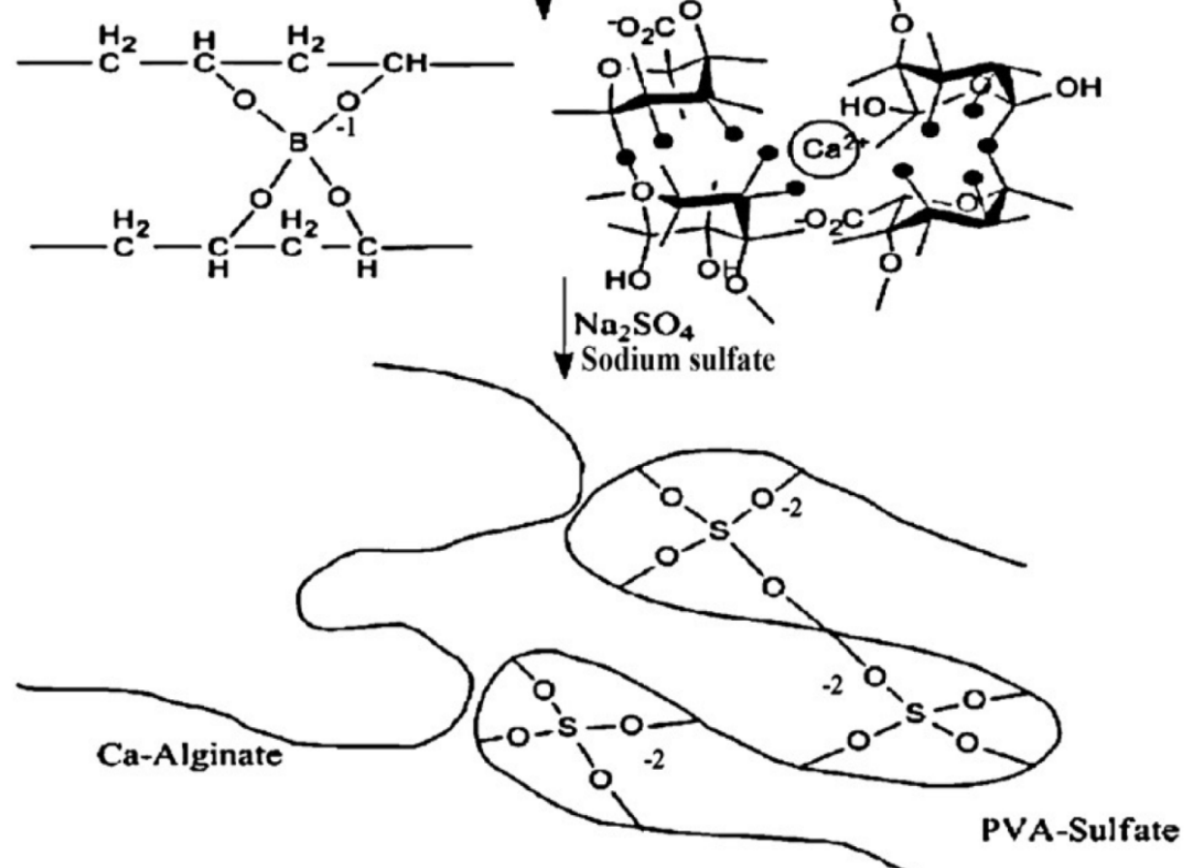

76 -

Fig. 6: Formation of beads (group S) [11]

\subsection{Test of relative mechanical strength}

To could assess mechanical strength, beads were centrifuged. The relative mechanical strengths of all kinds of bead are shown in Fig. 7. The group $\mathrm{N}$ had a very strong mechanical strength and are very difficult to break; they were not broken at agitation speeds lower than 2500 rpm. The group P showed a relatively weak mechanical strength, which might have been due to insufficient crosslinked, and were all broken when agitated at speeds over $2000 \mathrm{rpm}$. The group S had a medium mechanical strength.

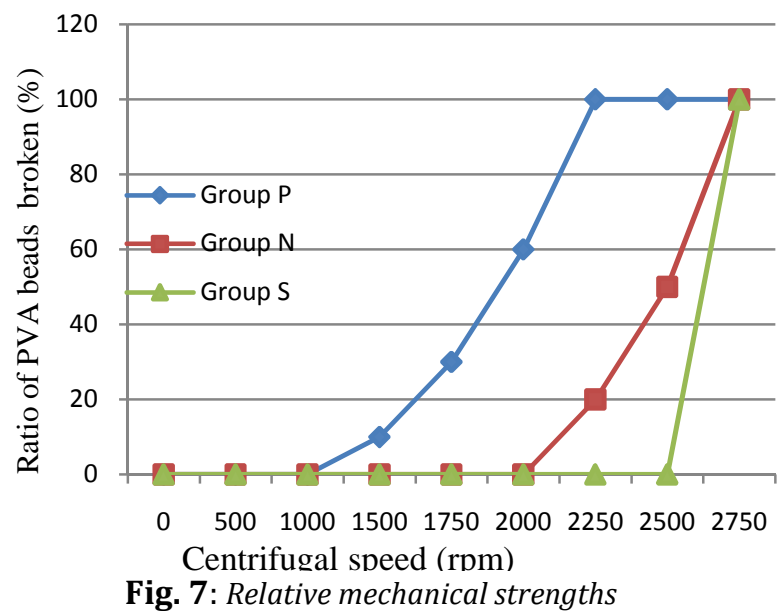

Fig. 7: Relative mechanical strengths 


\subsection{Test swelling of beads in the water}

The swelling of beads is shown in Table 6 and Fig. 8. The Group B was the weakest. The Group S was the strongest, they were almost be swelling very little, and special didn't solute in water. Although, the group $\mathrm{N}$ and Group P didn't solute, but they were be swelling much, from $4 \mathrm{~mm}$ in diameter at first to $7 \mathrm{~mm}$ and $8 \mathrm{~mm}$ in diameter at last, respectively. $\mathrm{Wu}$ and Wisecarver[10]suggested that the agglomeration problem is due to the insufficient crosslinking of the PVA by boric acid. The PVA beads of group $B$ which were not sufficiently crosslinked, could be dissolved almost completely after transferring into pure water for a few hours. After a few hours, the beads of group $\mathrm{N}$ and group $P$ were exhibited a very weak gel structure[17].

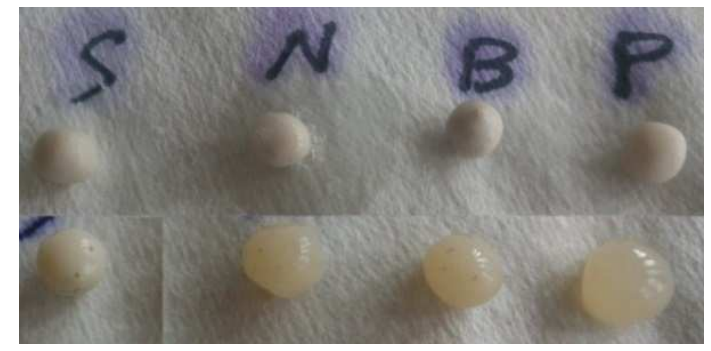

Fig. 8:Beads swollen after immersing in water

Table 6: The swelling of beads with temporal trend

\begin{tabular}{lllll}
\hline Time & Group B & Group N & Group P & Group S \\
\hline 0 & $4.0 \mathrm{~mm}$ & $4.0 \mathrm{~mm}$ & $4.0 \mathrm{~mm}$ & $4,0 \mathrm{~mm}$ \\
$2 \mathrm{~h}$ & $4.0 \mathrm{~mm}$ & $4.0 \mathrm{~mm}$ & $4.5 \mathrm{~mm}$ & $4,0 \mathrm{~mm}$ \\
1 day & $4.5 \mathrm{~mm}$ & $4.5 \mathrm{~mm}$ & $5.0 \mathrm{~mm}$ & $4,5 \mathrm{~mm}$ \\
2 days & $4.5 \mathrm{~mm}$ & $5.5 \mathrm{~mm}$ & $6.0 \mathrm{~mm}$ & $4,5 \mathrm{~mm}$ \\
3 days & $5.0 \mathrm{~mm}$ & $6.0 \mathrm{~mm}$ & $7.0 \mathrm{~mm}$ & $4,5 \mathrm{~mm}$ \\
4 days & $5.5 \mathrm{~mm}$ & $6.5 \mathrm{~mm}$ & $7.0 \mathrm{~mm}$ & $4,5 \mathrm{~mm}$ \\
5 days & $5.5 \mathrm{~mm}$ & $6.5 \mathrm{~mm}$ & $8.0 \mathrm{~mm}$ & $4,5 \mathrm{~mm}$ \\
7 days & $5.5 \mathrm{~mm}$ & $6.5 \mathrm{~mm}$ & $8.0 \mathrm{~mm}$ & $4,5 \mathrm{~mm}$ \\
14 days & $5.5 \mathrm{~mm}$ & $6.5 \mathrm{~mm}$ & $8.0 \mathrm{~mm}$ & $4,5 \mathrm{~mm}$ \\
\hline
\end{tabular}

\subsection{Check survival of bacteria after immobilization}

In Wilson Blair agar was available sodium sulfate and iron (III) chloride. In anaerobic condition, sulfite-reducing bacteria digests sulfate to hydrosulfide $\left(\mathrm{H}_{2} \mathrm{~S}\right)$. Hydrosulfide reacts with iron (III) to create FeS - black color. So, if Wilson Blair agar changes color after transplant beads inside, it means bacteria in beads can exist after immobilization process.

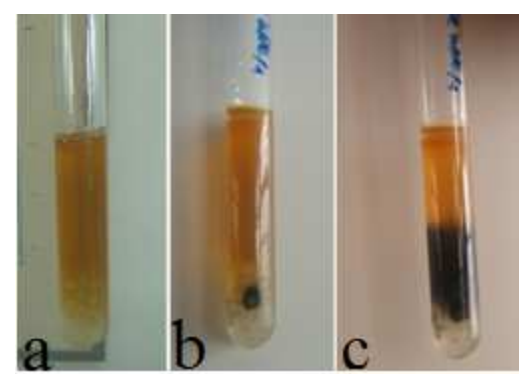

Fig. 9: Beads of group $S$ were transplanted in Wilson Blair agar: a) after 2 hours; b) after 24 hours; c) after 72 hours.

In this study, several beads of group $\mathrm{S}$ were transplanted inside Wilson Blair agar. Result (Fig. 9) demonstrated that this immobilization process is suitable.

\subsection{Test of performance in anaerobic reactor}

TOC removal performance of reactor (with presence of group S inside) is shown in Fig. 10. In first five days, effective treatment is only under $30 \%$, TOC residue is more and more arise after each add nutrient, $\mathrm{pH}$ in reactor is in low level $(<3.5)$. From fifth day and eighth day, $\mathrm{pH}$ is adjusted respectively by adding more 2 $\mathrm{ml}$ and $3 \mathrm{ml}$ of saturated $\mathrm{NaHCO}_{3}$ solution; $\mathrm{pH}$ oscillates around 6.2 to 6.5. From sixteenth day, performance of reactor increases and is stable at $80-87 \%$.

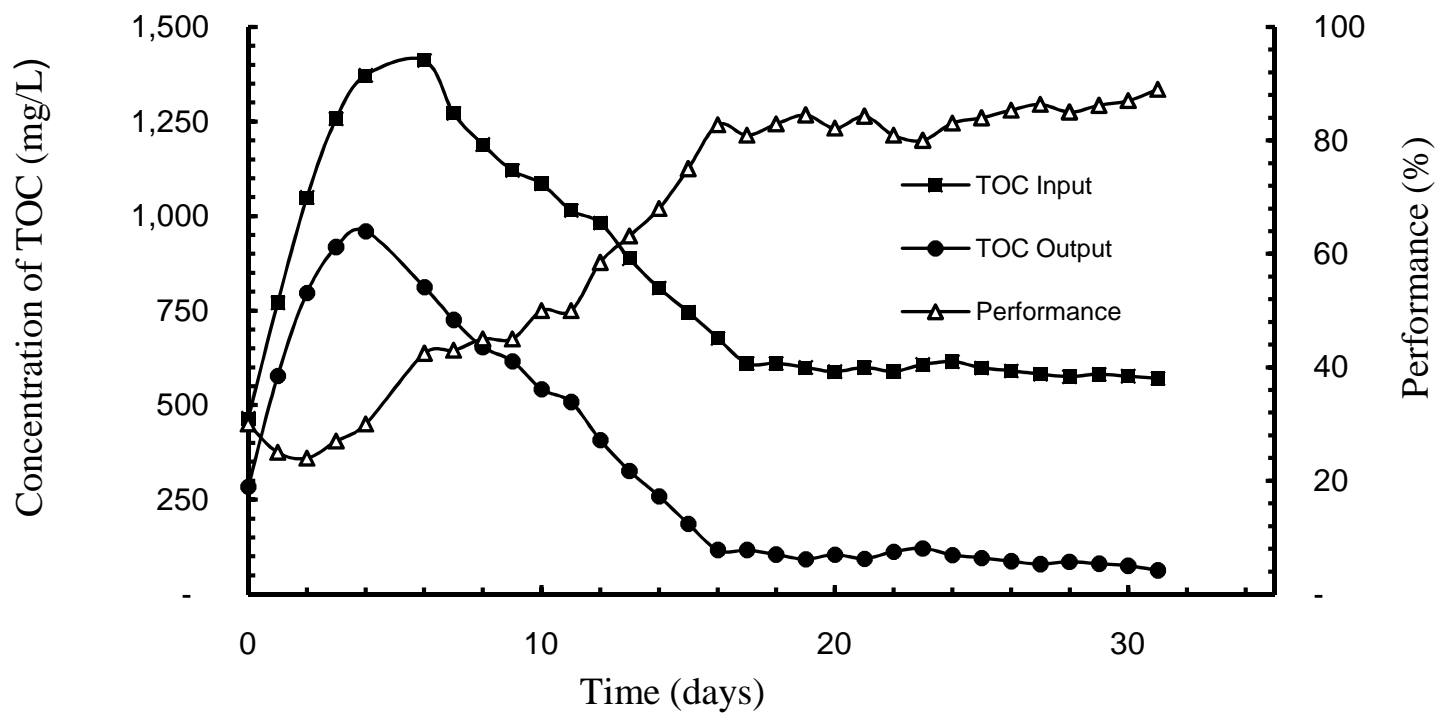

Fig. 10: TOC removal performance 


\section{Conclusion}

PVA is a cheap, non-toxic material and suitable for cell immobilization. But the agglomeration of PVA beads and the dissolve back of group $B$ are two problems that are encountered when using the PVA-boric acid method. Adding a small amount of sodium alginate in the PVA gel can prevent the agglomeration of PVA beads [10]. Group $\mathrm{N}$, group $\mathrm{B}$ and group $\mathrm{P}$ overcame both above disadvantages, but they swollen in water. Thus, it's not suitable for this research purpose. Only group $\mathrm{S}$ was the most suitable with the immersion time for solidification is very short; well-non swollen in water; the high mechanical strength. Especially, the TOC removal performance in the anaerobic reactor increased clearly with presence beads (group S). The PVA-sulfate method may be a promising and economical technique for cell immobilization.

\section{References}

[1] Vojtisek, V. and V. Jirku. (1983). Immobilized cells. Folia Microbiol (Praha). 28(4): p. 309-40.

[2] Ariga, 0., et al. (1987). Immobilization of Microorganisms with Pva Hardened by Iterative Freezing and Thawing. Journal of Fermentation Technology. 65(6): p. 651-658.

[3] Kuu, W.Y. and J.A. Polack. (1983). Improving Immobilized Biocatalysts by Gel Phase Polymerization. Biotechnology and Bioengineering. 25(8): p. 1995-2006.

[4] Freeman, A. and Y. Aharonowitz. (1981). Immobilization of Microbial-Cells in Crosslinked, Pre-Polymerized, Linear Polyacrylamide Gels - Antibiotic Production by Immobilized Streptomyces-Clavuligerus Cells. Biotechnology and Bioengineering. 23(12): p. 2747-2759.

[5] Hashimoto, S. and K. Furukawa. (1987). Immobilization of Activated-Sludge by Pva Boric-Acid Method. Biotechnology and Bioengineering. 30(1): p. 52-59.

[6] Ramaraj, B. (2007). Crosslinked poly(vinyl alcohol) and starch composite films. II. Physicomechanical, thermal properties and swelling studies. Journal of Applied Polymer Science. 103(2): p. 909-916.
[7] Khoo, K.M. and Y.P. Ting. (2001). Biosorption of gold by immobilized fungal biomass. Biochemical Engineering Journal. 8(1): p. 51-59.

[8] Hassan, C.M. and N.A. Peppas. (2000). Cellular PVA hydrogels produced by freeze/thawing. Journal of Applied Polymer Science. 76(14): p. 2075-2079.

[9] Gholap, S.G., J.P. Jog, and M.V. Badiger. (2004). Synthesis and characterization of hydrophobically modified poly(vinyl alcohol) hydrogel membrane. Polymer. 45(17): p. 5863-5873.

[10] Wu, K.Y.A. and K.D. Wisecarver. (1992). Cell Immobilization Using Pva Cross-Linked with Boric-Acid. Biotechnology and Bioengineering. 39(4): p. 447-449.

[11] Zain, N.A.M., M.S. Suhaimi, and A. Idris. (2011). Development and modification of PVA-alginate as a suitable immobilization matrix. Process Biochemistry. 46(11): p. 2122-2129.

[12] Choorit, W. and P. Wisarnwan. (2007). Effect of temperature on the anaerobic digestion of palm oil mill effluent. Electronic Journal of Biotechnology. 10(3): p. 376-385.

[13] Bach, L.T., Z.I. Bhatti, and K. Furukawa. (2002). Anaerobic Treatment of Sugary Wastewater by the UASB Process. Japanese Journal of Water Treatment Biology. 38(1): p. 11-20.

[14] Tchobanoglous, G., et al., Wastewater Engineering: Treatment and Reuse. Vol. 4. 2003: McGraw-Hill.

[15] Chang, C.-C. and S.-K. Tseng. (1998). Immobilization of Alcaligenes eutrophus using PVA crosslinked with sodium nitrate. Biotechnology Techniques. 12(12): p. 865-868.

[16] Chen, K.-C. and J.-Y. Houng, Cell Immobilization with Phosphorylated Polyvinyl Alcohol (PVA) Gel, in Immobilization of Enzymes and Cells, G. Bickerstaff, Editor. 1997, Humana Press. p. 207-216.

[17] Pillay, V., W. Sibanda, and M.P. Danckwerts. (2005). Sequential design of a novel PVA-based crosslinked ethylenic homopolymer for extended drug delivery. International Journal of Pharmaceutics. 301(1-2): p. 89-101.

[18] Gacesa, P. and N.J. Russell, The structure and properties of alginate, in Pseudomonas Infection and Alginates, P. Gacesa and N.J. Russell, Editors. 1990, Springer Netherlands. p. 29-49.

[19] Shibayama, M., et al. (1988). Sol-gel transition of poly(vinyl alcohol)-borate complex. Polymer. 29(11): p. 2066-2071.

ISO 10532:2008 - Water quality - Determination of $\mathrm{pH}$ ISO 8245: 1999 - Water quality - Guidelines for the determination of total organic carbon (TOC) and dissolved organic carbon (DOC). 